\title{
EL LEGADO OCULTO DE ANTONIO MACHADO A LA GENERACIÓN DE POETAS DEL MEDIO SIGLO
}

\author{
THE HIDDEN LEGACY OF ANTONIO \\ MACHADO TO THE SPANISH MID- \\ CENTURY GENERATION OF POETS
}

\author{
Xon de Ros \\ University of Oxford
}

Resumen: Los estudios dedicados a investigar la ascendencia de Antonio Machado en la generación poética del 50 han resaltado la crítica social y la reflexión metafisica como rasgos comunes en ambos. Este artículo se propone explorar el componente erótico, un aspecto poco estudiado en la poesía de Machado a pesar de la relevancia que tiene en la obra de sus apócrifos, examinando uno de los poemas tempranos de "Galerías» a la luz de su lectura por parte de Jaime Gil de Biedma. El análisis de las estrategias que generan el potencial erótico del poema machadiano, a través de enfoques proporcionados por teorías y poéticas del erotismo elaboradas por autores como George Bataille, Roland Barthes, Octavio Paz y Anne Carson, entre otros, revela una estructura de ecos y resonancias poéticas que evocan una figura mediadora del deseo. La reacción de Gil de Biedma sugiere una sensibilidad receptiva a esta veta del legado de Machado.

Palabras clave: erotismo; Antonio Machado; Charles Baudelaire; Jaime Gil de Biedma; poetas del 50; tradición poética; Michel Foucault; Georges Bataille;Anne Carson; Octavio Paz; triángulo erótico; mediador del deseo; eco poético.

Aвstract: Researchers working on the influence of Antonio Machado on the Spanish mid-1950s generation of poets have highlighted social critique and metaphysical reflexivity as common features in both. Prompted by Jaime Gil de Biedma's reading of one of Machado's earlier poems from the series 'Galerías', this essay explores the erotic component in the poem, an element under-researched in Machado's poetry despite its relevance to the writings of his apocryphals. Drawing on theories of eroticism proposed, among others, by Georges Bataille, Octavio Paz, Roland Barthes and Anne Carson, an analysis of the textual strategies that generate the erotic potential in Machado's poem reveals a network of echoes and 
poetic resonances which conjure up the figure of a mediator of desire. Gil de Biedma's reading suggests a sensibility receptive to this strand of Machado's legacy.

KeY words: eroticism;Antonio Machado; Charles Baudelaire; Jaime Gil de Biedma; poets of 1950; poetic tradition; Michel Foucault; Georges Bataille; Anne Carson; Octavio Paz; erotic triangle; mediator of desire; poetic echo.

amor que asombra, aguija, halaga y duele $y$ más se ofrece cuanto más esquivo

Antonio Machado, CLXVII: XI

Según Georges Bataille ([1957] 1986), el erotismo es el fundamento de la poesía, y los dos vectores del impulso erótico son el elegiaco y el amoroso. Por un lado, la prominencia de la lírica amorosa en el canon poético parece confirmar la conocida sentencia de Platón «en contacto con Eros todos se vuelven poetas» (Sympósion 196e 1-2) y, por el otro, la asociación del erotismo con la muerte se funda en que ambos representan la disolución de la individualidad del ser. Para Bataille, haciéndose eco de la teoría de Aristófanes en el Banquete de Platón, Eros denota el deseo de despersonalización y la búsqueda de una unión que resuelve la naturaleza fragmentada de la humanidad. Esta idea de conexión o continuidad que identifica el erotismo con la poesía es el punto de partida de una reflexión sobre la relación de Antonio Machado y los poetas del medio siglo, representados por Jaime Gil de Biedma, que voy a tratar aquí.

Como es bien sabido, la promoción del cincuenta tuvo como poeta tutelar a Antonio Machado y su epifanía se efectuó en torno a un acto de homenaje con motivo del aniversario de la muerte del poeta, tal como había sido el caso del grupo de poetas del 27 y Góngora. El lanzamiento cristalizaría a través de la gestión editorial de José María Castellet, que reunió a un elenco representativo en su antología publicada en Barcelona en 1960 por Seix Barral, titulada Veinte años de poesía española 1939-1959 y dedicada a la memoria de Antonio Machado. La tendencia dominante de la selección era la de poesía social o de compromiso, coincidiendo con la línea ideológica del editor, quien en el prólogo señalaba que la «vuelta a Machado» en la generación de medio siglo se refería «más al autor 
del Juan de Mairena, del Abel Martín y de Los complementarios que al poeta mismo» (Castellet, 1960: 101). El crítico Juan Antonio Masoliver ha subrayado la línea de continuidad de esta promoción poética con el Machado social y metafísico (2003: 72); sin embargo, hay un aspecto del legado del autor de Campos de Castilla a los poetas del medio siglo que la crítica ha pasado por alto y que me propongo examinar aquí. Se trata del elemento erótico, que no solo es un tema central en la obra del apócrifo Abel Martín, y en buena medida también del Cancionero de Juan de Mairena, sino también generalmente en la poesía de Machado. Recordemos el verso inicial del soneto que atribuye a su apócrifo epónimo "Antonio Machado»: "Nunca un amor sin venda ni aventura» (LIX, 5: II). Especialmente en su poesía amorosa hay una constante reflexión sobre la ausencia, que es un ingrediente fundamental de lo erótico. Además, su obra registra un interés por el personaje del libertino don Juan, que aparece en su poesía, prosa y drama. No hay que olvidar que Machado empezó su carrera como escritor en el semanario satírico La Caricatura, que contaba con miembros del mundo de la bohemia y la farándula, en un periodo en el que el país estaba experimentando lo que se ha llamado la "ola verde», una ola de erotismo reflejada en la proliferación de cabarets, cafés-cantantes y revistas de variedades, cuando en el argot teatral se acuñó la palabra "sicalíptico» para describir la insinuación pícara de carácter sexual que predomina en el género chico. Al mismo tiempo que el discurso científico y médico sobre la sexualidad se hacía cada vez más explícito.

No pondré en cuestión el juicio general de Castellet en cuanto a los textos de Machado que más influyeron en los poetas de la generación del 50; no obstante, al menos en el caso de Jaime Gil de Biedma, una de las figuras más representativas del grupo, resulta revelador encontrar repetidas referencias a la poesía de los primeros libros de Machado. Es cierto que uno de los capítulos de su ensayo sobre Jorge Guillén va precedido de un epígrafe proveniente de un artículo político escrito por Machado al final de su vida para Hora de España, pero el capítulo siguiente va encabezado por unos versos de una de las «Parábolas» de Campos de Castilla, que tienen un contenido fundamentalmente metapoético, y en el mismo ensayo también se cita elogiosamente el poema elegiaco "A la muerte de un amigo», 
de la misma colección ${ }^{1}$. Si bien Gil de Biedma menciona de pasada el nombre de Juan de Mairena en alguna entrevista, las referencias y alusiones a la poesía de Machado ocupan un lugar más destacado en su obra. El poema "Consejo», también de Campos de Castilla, es uno de los epígrafes de la colección Las personas del verbo que reúne la poesía completa hasta 1975 de Gil de Biedma, quien en una nota de autor explica su decisión de no incluir un poema publicado anteriormente, en el cual, según refiere, «deliberadamente conspiré para enmascarar la influencia de Jorge Guillén con imitaciones y collages de Antonio Machado» (1334) ${ }^{2}$. Una de las estrofas de «El viajero" de Soledades aparece citada apreciativamente en su ensayo sobre Espronceda, y en el prólogo a la edición catalana de Four Quartets, de T. S. Eliot, se cita uno de los proverbios de Machado y se hace referencia a otro $(1057,1060)$. En todo caso, ecos y alusiones machadianas se pueden rastrear en versos como «Mi infancia eran recuerdos de una casa» (cfr. Machado, «Retrato»), o "Carlos, querido amigo, lejano y tan presente» (cfr. Machado, «A José María Palacio»); y el texto "Poética» (988) recuerda mucho al ensayo de Machado «Problemas de la lírica» (1309-1310), e incluso contiene la frase latina ex nihilo que Machado utiliza en varias ocasiones en términos semejantes ${ }^{3}$. Ciertamente, Gil de Biedma fue un lector asiduo de Machado, a quien reconoce como «maestro» de su generación ${ }^{4}$, aunque en una entrevista parece querer distanciarse de su ascendencia: «Como poeta me parece espléndido, pero no creo que me haya influido mucho» (1192). A pesar de sus protestas, hay un aspecto de la poesía de Machado que sin duda hizo mella en el autor de Las personas del verbo, el poeta de su generación cuya poesía amorosa se destaca por la pasión erótica. En palabras de Javier Alfaya

1 Otras referencias a Machado se pueden espigar en el ensayo de 1960 titulado «Cántico: el mundo y la poesía de Jorge Guillén» (Gil de Biedma, 2010: 551-665; todas las citas en el texto son de esta edición).

2 Con respecto a las referencias machadianas en el poema suprimido, véase Jiménez y Morales, 2002: 214-216.

3 Las citas de Machado son de la edición de Oreste Macrì Antonio Machado. Poesía y prosa (1989), 4 vols. con numeración consecutiva; véase «Sobre las imágenes en la lírica» (1208), y «Dos preguntas de Tolstoy: ¿Qué es el arte? ¿Qué debemos hacer?» (1612-1615); las citas subsiguientes en el texto son de esta edición.

4 «Para mí es un grandísimo poeta que he leído mucho y que releo constantemente» (1286). 
(1981: 19), «quizás ningún poeta contemporáneo ha escrito con tan franco erotismo, ha expresado con tal garra la pasión amorosa ${ }^{5}$.

Se ha dicho que la tradición poética española carece de erotismo, y esa supuesta escasez se atribuye a razones históricas y sociales, en especial la influencia de la moral católica, aunque el número de antologías publicadas parece desmentir este juicio ${ }^{6}$. Sin entrar en polémica, lo que sin duda hace falta es un estudio teórico que categorice el género o géneros considerados eróticos, desde la poesía amatoria y mística a la obscena y pornográfica. A efectos de este trabajo me remito a la distinción que hace Michel Foucault en su Historia de la sexualidad entre dos tradiciones: la de ars erotica y la de scientia sexualis, esta última basada en el discurso confesional y aquella en el hermetismo y el misterio (1978: 57-58) ${ }^{7}$. A pesar de que la tradición de ars erotica haya tenido más desarrollo en culturas orientales y la scientia sexualis en Occidente, las dos tendencias a menudo se solapan, ya que la sexualidad es subyacente a ambas; pero si bien la scientia sexualis se caracteriza por la expresión reveladora, en el erotismo, como señala Octavio Paz, otro de los pensadores que ha indagado sobre la afinidad entre erotismo y poesía, la sexualidad se transfigura en metáfora y está guiada por la imaginación (1993: $10)^{8}$. Desde esta perspectiva, la poesía de Gil de Biedma se puede adscribir a la ciencia de la sexualidad, mientras que la de Machado se inclinaría hacia el ars erotica. Además, existe también una dimensión formal o estilística de lo erótico que, partiendo de las teorías

5 Véase también Arias, 1993.

6 Algunos ejemplos: José María Díaz Borque, Poesía erótica (Siglos XVI-XX) (Madrid, Ediciones Siro, 1977); Joaquín Caro Romero, Antología de la poesía erótica de nuestro tiempo (Paris, Ruedo Ibérico, 1973); Pedro Provencio, Antología de la poesía erótica española e hispanoamericana (Madrid, Edaf, 2003); Jesús García Sánchez y Marcos Ricardo Barnatán, Poesía erótica castellana del siglo X a nuestros días (Madrid, Júcar, 1974); Luce López Baralt y Francisco Márquez Villanueva, Erotismo en las letras hispánicas: aspectos, modos y fronteras (México, El Colegio de México, 1995).

7 Foucault expone en esta obra cómo la pasión amorosa, considerada en la Antigüedad como una enfermedad o casi una forma de locura, se transforma progresivamente en una dimensión esencial para la identidad individual, culminando en las teorías psicoanalíticas de la formación de la subjetividad; Harold Bloom aplica el modelo freudiano a la tradición poética en su obra The Anxiety of Influence: A Theory of Poetry (1973).

8 El juicio de Octavio Paz — «la poesía erotiza al lenguaje y al mundo porque ella misma, en su modo de operación, es ya erotismo» (1993:10) — refleja la analogía erotismo/poesía de Bataille. 
estructuralistas de Roland Barthes, ha ocupado entre otras tendencias a la crítica feminista. Según Barthes, el erotismo textual seduce al lector con un juego de vislumbres, creando una inestabilidad a nivel de significado que impide o al menos ralentiza su apropiación por parte del lector. Se trata de una reacción que vemos reflejada en la lectura de uno de los poemas tempranos de Machado por parte de Gil de Biedma.

La ocasión es el poema de Machado que Gil de Biedma trae a colación en una entrevista-coloquio en Granada en 1993, y que cita en su totalidad. Se trata de una silva arromanzada de catorce versos endecasílabos y heptasílabos que figura en la sección «Galerías» con el número LXII de las obras completas. Originalmente había aparecido en la revista Helios en mayo de 1904, y posteriormente se incluyó en la edición de Soledades. Galerías. Otros poemas de 1907, precisamente con el título de "Galerías». Llama la atención el tono exaltado que adopta Gil de Biedma, normalmente moderado en sus juicios, al evocar este poema de Machado, que le hace exclamar en distintos momentos: "¡Qué bien escribía y qué técnico más preciso y más exquisito era! [...] ¡Mi admiración por don Antonio Machado... ¡Caray! ¡caray! con don Antonio [...] don Antonio Machado era un gran poeta [...] Mi admiración por Machado es infinitamente mayor después de haber leído el poema» $(1143,1145,1150)$. Se refiere al siguiente:

Desgarrada la nube; el arco iris brillando ya en el cielo, y en un fanal de lluvia y sol el campo envuelto.

Desperté. ¿Quién enturbia los mágicos cristales de mi sueño? Mi corazón latía atónito y disperso.

... El El limonar florido, el cipresal del huerto, el prado verde, el sol, el agua, el iris...!, ¡el agua en tus cabellos!

Y todo en la memoria se perdía como una pompa de jabón al viento.

En el coloquio, Gil de Biedma procede a contar cómo durante años el poema de Machado fue un poema que «[le] fascinó, [le] sedujo, y que amaba profundamente» (1143), achacando la fascinación 
que ejerció sobre él al hecho de no acabar de entenderlo. No obstante, según explica, una vez desentrañado su significado el poema había perdido su magnetismo. En general la actitud de Gil de Biedma ante el poema refleja una experiencia que puede calificarse de erótica. La expresión que utiliza es elocuente en sus connotaciones sexuales: «este poema solía pasar las noches conmigo y ya no ha vuelto» $(1150)^{9}$. El poema de Machado le sirve para ilustrar una cita — «la poesía suele dar más placer cuando solo se entiende de un modo imperfecto o general» (1141)— que Gil de Biedma atribuye erróneamente a Coleridge, aunque se trata de un pensamiento más afin a la concepción del poeta como transmisor del misterio e incertidumbre del mundo, relacionado con la poética de Keats. Lo que viene a decir es que lo que se conoce, como lo que se posee, deja de ser objeto de deseo, ya que el deseo requiere la falta o ausencia del objeto. En todo caso su reacción nos invita a considerar las estrategias que generan el potencial erótico del poema machadiano.

En primer lugar, no sorprende encontrar la frase inicial «desgarrada la nube» en una de las Rimas de Bécquer (Rima IV):
Mientras las ondas de la luz al beso
palpiten encendidas, mientras el sol las desgarradas nubes de fuego y oro vista, mientras el aire en su regazo lleve perfume y armonías, mientras haya en el mundo primavera habrá poesía.

Aunque comparte el uso de asonancia y la alternancia de versos endecasílabos y heptasílabos, en el poema de Machado se puede distinguir la estructura del soneto shakespeariano, con tres estrofas de cuatro versos y dos finales de coda. En este sentido la forma elegida por Machado se corresponde con el tema, ya que los sonetos de Shakespeare exploran modos específicos de tensión amorosa que la crítica describe como «una liturgia erótica» (Lewis, en Culler, 2015: 120 y 207). Por otro lado, en las Rimas de Bécquer se establece claramente la analogía entre el deseo erótico y la creación poética, dejado de venirme por las noches, ya no me visita, ya es puta, diría, ya es mía» (1145). 
ambos movidos por la imaginación, que, como en la metáfora y en el sueño, hace visible una realidad inexistente y realiza la unión entre sujeto y objeto (vid. Fernández Utrera, 1994). En este caso, la alusión nos alerta del aspecto metapoético del poema machadiano.

Gil de Biedma celebra en este poema la economía de la anécdota concentrada en el verbo «desperté», donde ve confirmado el comentario del propio Machado de que ya en su primer libro, Soledades, se había anticipado a su tiempo con la eliminación de lo anecdótico $(1207)^{10}$. A diferencia de la lectura secuencial que ha prevalecido en la recepción critica del poema, Gil de Biedma nos ofrece una alternativa más cercana a la noción de negative capability de Keats. En su lectura, toda la acción del poema se desarrolla en un instante que registra la desorientación experimentada por el sujeto entre la realidad fenomenológica que percibe al despertar y las imágenes rescatadas del sueño. Aunque Gil de Biedma no elabora sobre las bases de su interpretación, es fácil justificar su lectura de la primera estrofa como confirmación de la realidad exterior por parte del sujeto con la presencia del adverbio temporal «ya». Al mismo tiempo, la vaguedad de la atmosfera en la primera estrofa y la nitidez de las imágenes en la tercera sirven para subrayar la equivalencia entre la realidad exterior y la onírica.

La lectura de Gil de Biedma ofrece una interpretación plausible, pero no proporciona una explicación cabal del lapso temporal efectuado con la pregunta «¿Quién enturbia los mágicos cristales de mi sueño?», que parece dirigirse directamente al lector, y que en todo caso no añade nada a la interpretación, o más bien la complica, incorporando el elemento extemporáneo de una presencia invisible. En la obra de Machado, los cristales, sea como vidrio transparente o como espejo reflector, representan la barrera interpuesta entre lo interior y lo exterior (Ribbans, 1971: 196-197). El enturbiamiento también tiene raigambre en la visión poética de Machado, en la que suele denotar confusión y equívoco (Ribbans, 1971: 194, 161 n. 17). El crítico alemán Hans Mattauch, rastreando la huella de Baudelaire en la poesía de Machado anterior a 1904, ha detectado la imagen de "los mágicos cristales de mi sueño» en uno de los poemas de Les fleurs du mal («Rêve parisien»), con el que establece

10 Para la mayoría de los críticos, el poema describe la interrupción de una visión real o soñada que da lugar a un ensueño donde las imágenes se mezclan con el recuerdo para terminar disolviéndose en la conciencia. 
una correspondencia temática. Asimismo, es tentador ver en los «mágicos cristales» de Machado una alusión al poema en prosa de Baudelaire «Le mauvais vitrier», donde los «cristales mágicos» sirven para acceder a una realidad poética superior a la real. Pero es en el soneto de Les fleurs du mal titulado "La mort des amants» donde aparece la expresión «cristales turbios» - les mirroirs ternis- que parece prefigurar la invocación de Machado en el poema presente:

Et plus tard, un Ange, entr'ouvrant les portes, viendra ranimer, fidéle et joyeux, les mirroirs ternis et les flammes mortes.

Tampoco es difícil asociar la imagen inicial de la nube desgarrada con Baudelaire. Las nubes aparecen en el poema en prosa que abre la serie de El spleen de París, donde el enigmático extranjero declara su predilección por el fenómeno: «'aime les nuages... les nuages qui passent... là-bas... les merveilleux nuages!», que son calificadas en otro poema en prosa («La soupe et les nuages») como «les merveilleuses constructions de l'impalpable». En otro de los poemas de Les fleurs du mal («Horreur sympathique») se presenta el motivo de la nube unido a la acción de desgarramiento:

\section{Cieux déchirés comme des grèves en vous se mire mon orgueil; vos vastes nuages en deuil sont les corbillards de mes rêves.}

Al mismo tiempo, «desgarrado» puede tener en castellano un sentido figurado relacionado con la angustia existencial que, como sugiere George Steiner, es afin a la sensibilidad descrita por el término spleen tal como lo utiliza Baudelaire ${ }^{11}$. Los ecos y alusiones baudelaireanas proliferan en el poema de Machado y, como veremos más adelante, esta presencia es importante para desentrañar la calidad erótica del poema que nos ocupa.

Aquí, la imagen inicial de desvelamiento va seguido de una inesperada pausa. La asociación de la nube con un tejido recuerda la concepción del erotismo formulada por Roland Barthes, que, utilizando la imagen de una prenda de vestir sobre el cuerpo, lo sitúa

11 «El uso del spleen por Baudelaire [...] transmite el parentesco, la simultaneidad de la espera exasperada, vaga — ¿pero de qué? - con el desgarro gris» (Steiner, 1977: 20). 
en el espacio donde se entreabre la tela ${ }^{12}$. El punto y coma (con la elisión del conector consecutivo) es la primera brecha que aparece en un poema donde abundan las lagunas. Tras la pausa aparece el arcoíris, la imagen emblemática del poema que se repite cuatro veces, una con la abreviación de iris, que establece una relación anfibológica con la pupila del ojo, subrayando la cualidad visual del poema, $\mathrm{y}$ dos de ellas de forma indirecta, primero convertido en un fanal de lluvia y sol, y al final del poema invocado en la refracción de la luz que se realiza en la superficie de la pompa de jabón irisándola. La estructura circular de la pompa ha sido prefigurada en la anáfora de la primera estrofa, con la presencia del hipérbaton que retrotrae el movimiento del verso, y que junto con el participio «envuelto» sugiere un estado de inmersión en la cópula simbolizada en el fenómeno del arcoíris. La repetición del sonido /i/, la presencia de encabalgamiento y la fusión realizada mediante sinalefa en cada uno de los versos de la estrofa inyectan un sentimiento de anticipación, inminencia y movimiento en la imagen, un efecto reforzado con el uso del gerundio.

La segunda estrofa introduce una ruptura del régimen de visibilidad al declarar su presencia el sujeto lírico, que traslada al lector al espacio interior de la conciencia. La pregunta produce una asincronía cuya interferencia con la lógica temporal sugiere la perspectiva telescópica o desdoblada de la auto-conciencia. En todo caso, como ya se ha indicado, la referencia a los cristales sirve para marcar la distancia entre el sujeto y el objeto. La incertidumbre expresada en la pregunta se refleja en la reacción de desconcierto y despersonalización del sujeto lírico, que describe un estado de alteración emocional. La amenaza de desintegración del sujeto parece responder a la disolución de límites figurada en el paisaje precedente.

Después de la pausa estrófica se ofrece una nueva evocación, ahora consistente en una enumeración. Las primeras imágenes del limonero y el cipresal tienen un significado emotivo para Machado relacionado con el recuerdo de su infancia. A continuación, reaparecen los elementos del paisaje descrito en la primera estrofa. La diferencia aquí es la desconexión entre las imágenes — nótese que el «arco» del arcoíris ha desaparecido-, que ahora se presentan yuxtapuestas, separadas por comas y contenidas entre signos ortográficos,

12 En la formula original: «L'endroit le plus érotique d'un corps n'est-il pas là où le vêtement bâille?» (Barthes, 1973: 19). 
que actúan como muros de contención, todo ello reforzado por la coincidencia de las pausas versales y las unidades sintagmáticas. La lista culmina con una imagen de epifanía erótica representada en una sinécdoque del cuerpo, presumiblemente femenino, que ocupa un verso completo entre signos de exclamación. La profusión de puntuación sugiere una conciencia de límites y una voluntad de auto-control.

Así pues, desde esta perspectiva, el sujeto que aparece en la segunda estrofa se sitúa en la intersección de la dialéctica que se establece en el poema entre la percepción visual unificadora y la actividad diferenciadora de su actualización en el discurso.

No sorprende que la interpretación de los dos versos finales, donde aparece el motivo de la pompa de jabón, se haya relacionado con una poética de la temporalidad, un tema desarrollado por Machado en su obra ensayística que ha ocupado un lugar predominante en los estudios machadianos. La pompa de jabón, asociada al tema de la vanidad en la iconografia, puede interpretarse como una imagen de desengaño. La lectura literal de Geoffrey Ribbans (1971), en la que los recuerdos generados por el sueño se desvanecen como una pompa de jabón en la memoria, se ha proyectado en interpretaciones existenciales y metafísicas donde predomina, en mayor o menor medida, el elemento nihilista. Mientras que para Robert Havard (1988), que interpreta el poema dentro del marco de la fenomenología de Bergson, la pompa de jabón encarna la evanescencia de la durée asociada con la memoria involuntaria cuya experiencia se ve descrita en la estrofa anterior, Ricardo Gullón ve en la imagen «la constatación de un fracaso total» del subjetivismo radical asociado con el paysage d'âme simbolista, aunque reconoce que la conclusión no concuerda enteramente con el valor que generalmente se otorga a la memoria en la obra de Machado (1963:150-53). Según Oreste Macrì, la imagen de la pompa de jabón es una de las empleadas por Machado para ejemplificar la angustia existencial heideggeriana (868-869), apoyándose en la cita de uno de los fragmentos de Juan de Mairena donde aparece el motivo identificado con la conciencia:

A todo despertar [...] se adelanta una mosquita negra cuyo zumbido no todos son capaces de oír distintamente, pero que todos de algún modo perciben. De esta pinta diminuta y sombría surge el globo total, la irisada pompa de jabón de nuestra conciencia (2363). 
Sin embargo, hay que tener en cuenta que la cita proviene de un artículo publicado por Machado en enero de 1938 en Hora de España, en el contexto del pesimismo de los últimos meses de la guerra y cuando la derrota republicana era inminente. Treinta años antes Machado había utilizado el mismo motivo con un tono muy diferente en un poema publicado en 1909 en La Lectura, que luego encabezaría la serie de «Proverbios y cantares» (CXXXVI: I) de Campos de Castilla, donde dice:
Yo amo los mundos sutiles, ingrávidos y gentiles como pompas de jabón. Me gusta verlos pintarse de sol y grana, volar bajo el cielo azul, temblar súbitamente y quebrarse.

La impermanencia que expresa este poema informa el enfoque de Gil de Biedma, más cercano a la psicología de la experiencia, que, aplicado a la composición que nos ocupa, describe un momento «impreciso y muy breve» en el cual «el sueño y lo real se presenta[ba]n con la misma urgencia» (1144) ${ }^{13}$. Esta habilidad de concebir dos perspectivas simultáneamente, una literal y otra figurada, se realiza en la metáfora, cuya visión integradora o estereoscópica encuentra una representación en la imagen de la pompa de jabón. En este marco, el referente sería el deseo mismo, cuya satisfacción se presenta como inalcanzable. Con esta conclusión se puede explicar el cambio efectuado por Machado al sustituir el verbo que figuraba en la versión original, «se rompía», en ediciones sucesivas primero por «alejarse» y finalmente por "perderse», reemplazando así la idea de cancelación por la de prórroga, que se ajusta mejor a la exigencia de insatisfacción que estimula el deseo erótico.

La paradoja del placer generado por la insatisfacción del deseo es el tema del ensayo de la poeta y clasicista canadiense Anne Carson, cuyo título Eros the bittersweet (1986) invierte el apelativo utilizado por Safo, quien se refiere a Eros con una expresión más cercana a la

13 «La potencia de realidad de lo soñado es idéntica a la potencia de realidad de lo real» (1444). 
«dulce queja» lorquiana ${ }^{14}$. En su estudio, Carson examina la estructura del deseo en el lenguaje y el pensamiento de los poetas líricos y pensadores de la Antigüedad griega, considerando la analogía que los textos establecen entre el lenguaje y el erotismo, vinculados por su relación paradójica con el objeto. Esta asociación se establece en el poema de Machado con la palabra que cierra el poema, ya que el viento es un elemento asociado a su vez con el lenguaje y el deseo, un significado que aparece en otros poemas de la colección, como en "Llamó a mi corazón, un claro día, / con un perfume de jazmín, / el viento» (LXVIII), «La alameda conversa con el viento» (XCI), «el viento me ha traído tu nombre en la mañana» (XII). Incidentalmente, la presencia combinada del arcoíris y el viento evoca una de las cosmogonías griegas, que encontramos en textos de Alceo, poeta contemporáneo de Safo, en la que Eros aparece como producto de la unión de Iris, la mensajera de los dioses, y Céfiro, uno de los dioses del viento.

Como hemos visto, la estructura concéntrica del poema incluye una tercera perspectiva que introduce una incongruencia temporal en la diégesis, y cuyo sujeto se sitúa en un espacio interior al proceso de la escritura. Se trata de una voz intermedia en la que el sujeto es también el objeto en el que recae la acción ${ }^{15}$. La equivocación a la que se alude con el verbo "enturbiar» podría interpretarse a la luz de la teoría freudiana del trabajo del sueño, donde el deseo latente se manifiesta mediante un proceso de encubrimiento basado en mecanismos psíquicos de condensación y desplazamiento. Así pues, en lugar de ofrecer un acceso directo al objeto de deseo, las imágenes oníricas funcionarían como jeroglíficos. Por consiguiente, dentro del paradigma psicoanalítico, y coincidiendo al menos parcialmente con la interpretación de Gil de Biedma, la tercera estrofa consistiría en fragmentos oníricos de una cadena asociativa, mientras que la primera estrofa correspondería a la elaboración secundaria donde se amalgaman e integran las imágenes dispersas del sueño al despertar. En la teoría freudiana, el proceso de desplazamiento y condensación está predicado sobre la hipótesis de la energía libidinal

14 La traducción al castellano refleja la expresión de Safo: Anne Carson, Eros el dulce-amargo (trad. Mirta Rosenberg, Buenos Aires, Fiordo, 2015).

15 Para la figuración de la voz intermedia, véase Barthes, [1966] 1970: 134-145, donde, siguiendo la pauta de Émile Benveniste, afirma que, en la voz intermedia, entre pasiva y activa, «the subject is immediately contemporary with the writing, being effected and affected by it» (143). 
del individuo, integrada en la categoría más amplia de Eros, que denota el instinto vital. Freud se refiere en varias ocasiones a aspectos coincidentes entre su teoría de la libido y el concepto de Eros en Platón. Precisamente en La interpretación de los sueños se menciona apreciativamente el comentario de Platón sobre los deseos reprimidos que se manifiestan en los sueños (Freud [1899] 1976:134, 782).

No obstante, la imagen de la pompa de jabón no invita a indagar en el posible contenido latente del sueño, sino que deja el enigma literalmente en suspenso. Conviene recordar que en la primera versión publicada del poema había un espacio abierto entre la primera estrofa y el resto del poema, poniendo de relieve la correspondencia entre esta estrofa y el motivo de la pompa de jabón del verso final.

Como objeto que solo adquiere visibilidad por su capacidad de reflejar y refractar la luz, la pompa de jabón es una imagen paradójica, la figura de un deseo cuyo referente es el deseo mismo. Bajo este enfoque, el motivo se convierte en una representación de la experiencia paradójica de Eros. Conviene recordar que la figura retórica de la paradoja tiene un papel prominente en la poética y el pensamiento de Machado, y su correspondencia con Eros se refleja en una reflexión de Abel Martín acerca de la dinámica de acercamiento y separación que se establece en torno al objeto erótico, que funciona "como un imán que al atraer repele» $(678)^{16}$.

Al mismo tiempo la presencia de la pompa de jabón subraya el marcado carácter visual del poema. La asociación de Eros con la vista se refuerza con la palabra «iris», y la atención de Machado a la calidad de la luz, el color y la textura, a la composición y a los elementos individuales de la naturaleza, revelan un deleite relacionado con la mirada. Este énfasis en la percepción visual recuerda el pensamiento de Mairena de que «lo poético es ver, y como toda visión, requiere distancia», la cual, a su vez, es «un requisito del deseo» (1966).

La vista es también el sentido que gobierna la palabra escrita, y si juzgamos por la reacción de Gil de Biedma, puede decirse que la relación que establece el poema entre el lector y el texto es esencialmente erótica. El estudio mencionado de Anne Carson demuestra que la estructura del deseo se traduce en las estrategias textuales de los autores griegos mediante tácticas de triangulación, donde el triángulo erótico se realiza cuando los tres componentes

16 Sobre la figura de la paradoja en la obra de Machado, véase Johnston, 2002. 
del deseo (sujeto, objeto y lo que se interpone entre ellos) se hacen visibles (Carson, 1986:16). El poema de Machado también presenta una tensión dinámica entre conflicto y unión articulada en una sucesión de figuraciones triangulares. La superación del obstáculo al inicio del poema presupone una configuración triangular entre la nube, el sol y la lluvia, que se resuelve en una síntesis de los dos últimos en la imagen del arco iris. Un nuevo desgarramiento, en este caso textual, se produce con el paso del contexto referencial al autorreferencial en la segunda estrofa, cuando una misteriosa fuerza invisible se interpone entre el sujeto y la visión y se resuelve en el desdoblamiento o «dispersión» del sujeto. Finalmente, otro triángulo se establece al final de la tercera estrofa con la invocación de una presencia externa, un «tú» distinto del sujeto, que sitúa al lector en la posición de testigo de una comunicación privada.

Estas triangulaciones se corresponden a nivel formal con las tres estrofas iniciales, cada una de ellas formada por tres heptasílabos y un endecasílabo que rompe la regularidad del verso y la simetría estrófica. Dentro de esta estructura se pueden detectar estrategias de desplazamiento y de retención en la posición de los verbos al final de los versos y en la de los adjetivos, detrás de los sustantivos, además de elipsis, pausas y lagunas temporales. Estos elementos sugieren alejamiento y se contraponen a la insistencia en el uso de la sílaba «en» que denota integración (en el cielo; en un fanal; envuelto; enturbia; quién; en tus cabellos; en la memoria; viento).

En su ya clásico estudio sobre la estructura del deseo en la novela, René Girard (1965) examina la dialéctica que se establece entre el sujeto y el objeto a través de una tercera figura que denomina «mediador del deseo», en una articulación triangular que pone de relieve el carácter intrasubjetivo y mimético de la relación erótica. En el modelo elaborado por Girard, el impulso del sujeto hacia el objeto de deseo es fundamentalmente imitativo. Lo que estimula al sujeto no es tanto el objeto como la percepción del deseo en el otro, una figura cuyo prestigio trata de emular. La relevancia de esta figura mediadora en el triángulo erótico desplaza al objeto, ya que en última instancia se trata de un impulso hacia el mediador.

Siguiendo la lógica de este modelo, debemos buscar al mediador del deseo machadiano en los espacios donde se hace visible la estructura triangular. Las alusiones a Baudelaire que contiene el poema de Machado sugieren que, al menos en esta época, pudo haber sido 
el mediador del deseo para su poesía. Hans Mattauch (2003) ha trazado el origen del uso metafórico del concepto de "galerías» en el elogio de la poética de Baudelaire realizado por Huysmans en su obra $\grave{A}$ rebours. La posibilidad de que esta obra fuera la fuente de Machado, estimulando su relectura de Les fleurs du mal en 1903, es una hipótesis tan sugerente como plausible ${ }^{17}$. En el poema que nos ocupa ya hemos comentado el eco de Baudelaire en la expresión "cristales mágicos», que puede extenderse al concepto de "enturbiamiento» y al de "desgarro». Además, la mención de los cabellos mojados nos remite al conocido poema erótico de Baudelaire «La chevelure», donde el poeta emplea metáforas acuátiles para describir la voluptuosidad que se desprende de la cabellera femenina ${ }^{18}$. Por último, la pompa de jabón también está presente en Les fleurs du mal. En «L'amour et la crane», una figura de Eros fabrica pompas de jabón que flotan en el aire y luego se esfuman: "comme un songe d'or»"

Unos meses antes de la publicación del poema en Helios, en agosto de 1903, Unamuno había publicado una carta abierta a Machado en la misma revista instándole a que abandonara a los poetas franceses y refiriéndose a «las atrocidades de Baudelaire», el poeta maldito a quien Max Nordau había calificado de decadente y erotómano (Aggeler, 2009: 18). Quizás la pompa de jabón pueda interpretarse como una concesión a la crítica de Unamuno. Sin embargo, como argumenta Mattauch, la publicación de la serie de «Galerías» en Helios representa en sí misma un gesto de rebeldía, y sugiere que, a pesar de la censura de Unamuno, la relación textual de Machado con Baudelaire seguía en vigor.

Hasta aquí he utilizado los términos «alusión»y «eco poético» indistintamente, pero, aunque estén estrechamente relacionados, conviene distinguirlos. A diferencia de la alusión propiamente dicha, en el eco el sentido del original no interviene en el significado del poema receptor, y su inserción puede haber sido no intencionada ${ }^{20}$.

17 Mattauch describe el encuentro de Machado con la metáfora huysmansiana como un «flechazo (poético)» (2003: 228), una expresión que coincide con el tema del presente artículo.

18 Precisamente unos versos de «La chevelure» aparecen en el epígrafe de los diarios de Gil de Biedma recogidos en Retrato del artista en 1956 (257).

19 En el epílogo a la edición de Les fleurs du mal de 1861, Baudelaire se refiere al oro para simbolizar la poesía: «tu m'as donne de la boue et j’en di fait de l'or» («Or et la boue»).

20 Véase Hollander, 1981, especialmente el capítulo IV. 
Su campo de acción se remite al interior del poema en el que reaparece y a los poetas posteriores que son capaces de percibir su presencia.

Ciertamente, el juego de resonancias internas del poema machadiano - asonancia, anáfora, aliteración, recurrencias fonológicas y léxicas - invita a identificar los ecos poéticos que contiene. En este caso una tarea fácil para un poeta como Gil de Biedma, que conocía bien la obra de Baudelaire, ya patente en el ensayo que le dedica en 1961 — «Emoción y conciencia en Baudelaire» (533544) - y en las numerosas referencias repartidas por su obra. Sin duda, los destellos de esta presencia subliminal no habrían pasado desapercibidos a un poeta que se declara deudor de Baudelaire. Más aún porque Gil de Biedma concibe la creación poética en términos muy similares a los de Harold Bloom, quien sostiene que todo poema se genera sobre otro poema anterior. Gil de Biedma también considera el pensamiento poético como un ejercicio de la memoria. En sus propias palabras: «la poesía solo tiene sentido en relación con los poemas que le han precedido [...] a partir de lo cual uno introduce su mínima diferencia significativa» (1128). Esta conectividad inherente de la poesía constituye a fin de cuentas su potencial erótico. Un potencial que, a su vez, se realiza en su poética, que Octavio Paz describe como «erótica verbal» o «erotización del lenguaje» (1993: 10).

Bajo este enfoque, es interesante considerar la ya famosa frase de Gil de Biedma: «Yo creía que quería ser poeta, pero en el fondo quería ser poema», donde expresa el deseo de trascender los límites de la identidad individual para, según explica, «existir en el orden de realidad en que existen los poemas $»^{21}$. Gil de Biedma concluye la nota con la frase pronunciada por Hamlet antes de morir: «y lo demás es silencio». Hay que recordar que, por entonces, cuando escribió la nota autobiográfica, Jaime Gil de Biedma había dejado de escribir poesía ${ }^{22}$.

21 «Nota autobiográfica» (enero de 1982) incorporada a la contracubierta de la segunda edición de Las personas del verbo (Barcelona, Seix Barral, 1982); pp. 81-82 por la edición que manejo.

22 «El último poema lo escribí en el 1982 [...] no creo probable que vuelva a escribir poemas» (entrevista con Alfonso Armada publicada en El País el 12 de diciembre de 1988 [https://elpais.com/diario/1988/12/12/cultura/597884406_850215. html (consultado el 30/08/2019)]. 
El vínculo entre creación y destrucción en el erotismo es subrayado por Bataille: «la poesía conduce al mismo lugar que todas las formas del erotismo - a la mezcla y la fusión de objetos separados, nos conduce a la muerte, y a través de la muerte a la continuidad» ([1957] 1986: 25) ${ }^{23}$.Volviendo brevemente a las «Galerías» de Machado, no parece casual que el único otro poema de la serie que comienza con un participio de pasado sea «Desnuda está la tierra» (LXXIX), que contiene los conocidos versos « ¿Qué buscas, / poeta, en el ocaso?», donde se refleja la tríada erotismo, muerte y poesía. La idea de tradición literaria, como nos recuerda Jonathan Culler en su Teoría de la lírica, es distinta de la filiación genética o biológica, ya que la tradición se transforma a medida que nuevos miembros revelan aspectos latentes en sus predecesores (2015: 45). En la poesía de Machado, el erotismo, a menudo encubierto y textual, es una característica que no puede pasar desapercibida a ningún lector atento de su obra, como sin duda lo fueron los poetas de la generación del 50. Al menos en la reacción de Gil de Biedma, como espero haber demostrado, parece confirmarse tácitamente esta conexión erótica que forma parte del legado de la escritura de Machado.

23 «Poetry leads to the same place as all forms of eroticism - to the blending and fusion of separate objects, it leads us to death, and through death to continuity». La traducción del inglés es mía. 


\section{BIBLIOGRAFÍA}

Aggeler, William F. (2009). Baudelaire Judged by the Spanish

Critics, 1857-1957, University of Georgia Press.

Alfaya, Javier (1981). «Jaime Gil de Biedma: una poesía humana e impura», en Jaime Gil de Biedma, Antología poética, Madrid, Alianza.

Arias, Consuelo (1993). «(Un)veiling Desire: Configurations of Eros in the Poetry of Jaime Gil de Biedma», Anales de la Literatura Española Contemporánea, 18, 1-2, pp. 113-136.

Barthes, Roland ([1966] 1970). «To Write: An Intransitive Verb?», en The Structuralist Controversy: The Languages of Criticism and the Sciences of Man, eds. Richard Macksey y Eugenio Donato, Baltimore \& London, The Johns Hopkins Press, pp. 134-145. (1973). Le plaisir du texte, Paris, Éditions du Seuil.

Bataille, Georges ([1957]1986). Erotism, Death and Sensuality, trans. Mary Dalwood, San Francisco, City Lights.

Baudelaire, Charles (1968). Oeuvres completes, Paris, Éditions du Seuil.

BLoom, Harold (1973). The Anxiety of Influence: A Theory of Poetry,

New York and Oxford, Oxford University Press.

Carson, Anne (1986). Eros the Bittersweet, Champaign: Illinois, Dalkey Archive Press.

Castellet, José María (ed.) (1960). Veinte años de poesía española (1939-1959), Barcelona, Seix Barral.

Culler, Jonathan (2015). Theory of the Lyric, Cambridge Mass., Harvard University Press.

Foucault, Michel (1978). History of Sexuality: An Introduction, trad. Robert Hurley, Harmondsworth, Penguin.

Freud, Sigmund ([1899] 1976). The Interpretation of Dreams, trad. James Strachey, ed. Angela Richards, Harmondsworth, Penguin, The Pelican Freud Library, vol. IV.

Gil de Biedma, Jaime (1988). «No creo que vuelva a escribir un solo verso más» (entrevista con Alfonso Armada), El País, 12 diciembre. [https://elpais.com/ diario/1988/12/12/cultura/597884406_850215.html (consultado el 30/08/2019)].

— (2010). Obras. Poesía y prosa, introd. James Valender, ed. Nicanor Vélez, Barcelona, Galaxia Gutenberg / Círculo de Lectores.

Girard, René (1965). Deceit, Desire and the Novel: Self and Other in Literary Structure, trad.Yvonne Freccero, Baltimore, Maryland, The Johns Hopkins Press.

Gullón, Ricardo (1963). Direcciones del modernismo, Madrid, Gredos. 
Havard, Robert G. (1988). From Romanticism to Surrealism: Seven Spanish Poets, Totowa, NJ, Barnes \& Noble Books, 73-81.

Hollander, John (1981). The Figure of Echo: A Mode of Allusion in Milton and After, University of California Press.

Jiménez, José Olivio y Carlos Javier Morales (2002). Antonio Machado en la poesía española. La evolución interna de la poesía española 1939-2000, Madrid, Cátedra.

Johnston, Philip G. (2002). The Power of Paradox in the Work of Spanish Poet Antonio Machado (1875-1939), Lewiston, Edwin Mellen Press.

Macrì, Oreste (ed.) (1989). Antonio Machado. Poesía y prosa, Madrid, Espasa Calpe, 4 vols. Masoliver Ródenas, Juan Antonio (2003). «Carlos Barral: Complicidad y singularidad del orfebre», en La poesía española del siglo xx y la tradición literaria, eds. Trevor Dadson y Derek Flitter, University of Birmingham, pp. 94-110.

Mattauch, Hans (2003). «Las Galerías de Antonio Machado: origen y evolución de una metáfora central de su poesía», Revista de Literatura, 65, 129, pp. 225-235.

Paz, Octavio (1993). La llama doble. Amor y erotismo, Barcelona, Seix Barral.

Ribbans, Geoffrey (1971). Niebla y soledad. Aspectos de

Unamuno y Machado, Madrid, Gredos.

Steiner, George (1977). «El Gran Ennui», en En el castillo de Barbazul, trad. Hernando Valencia Goelkel, Madrid, Guadarrama, pp. 9-30. 